\title{
User motivation, energy prosumers, and regional diversity: sociological notes on using shallow geothermal energy
}

\author{
Alena Bleicher ${ }^{1 *}$ and Matthias Gross ${ }^{2}$
}

* Correspondence:
alena.bleicher@ufz.de
${ }^{1}$ Helmholtz Centre for
Environmental Research, UFZ,
Permoser Str. 15, 04318 Leipzig,
Germany
Full list of author information is
available at the end of the article

available at the end of the article

\begin{abstract}
In this paper, we shed light on some sociocultural aspects underlying the use of shallow geothermal energy and point to relevant research on the utilization and public understanding of geothermal energy. We show how societal components such as user preferences in heating and cooling, users' involvement in co-designing technology and producing energy, or country-specific administrative procedures influence the development of the technologies. We rely on existing studies and statistics and also on our own fieldwork (expert interviews) that has been carried out in 2013 and 2014 in Germany. Although we will focus on the cases in Germany, where shallow geothermal technologies have spread in a short time and evoked diverse forms of engagement from social actors, we also include comparative information from other countries.
\end{abstract}

Keywords: Shallow geothermal technology; Sociotechnical system; Motivational factors; Framing technology

\section{Review}

Geothermal heat has been in use for a long time by human societies, in particular at places where it is easily accessible (e.g., hot springs). At the beginning of the twentieth century, the exploitation of this energy source at a commercial scale started in Italy (in Larderello in 1911), Iceland (1928), and New Zealand (1958) by using the advantageous geological situation near tectonic plate boundaries (Garnish 1976). Since then, two technological families have been developed in order to extract energy from the earth at any place in the world.

The older family of technologies makes use of shallow geothermal heat on the household level for heating, hot water provision, and cooling. While the first patent for a ground-coupled heat pump was published in 1914, the number of installations has only increased since the 1970s especially in Sweden and since the 1980s in the USA as well as recently also in Switzerland and Germany (Lund et al. 2011).

Since the 1970s, another family of geothermal energy technology was developed in order to tap into geothermal energy at depths of several thousand meters in order to provide electricity. Thereby, two types of use have to be distinguished: (a) hydrothermal applications that make use of hot water reservoirs in several thousand meters depth and (b) petrothermal applications that use water that has been injected 
and heated bypassing hot rocks in several thousand meters depth. Although both approaches aim on producing electricity, currently thermal use dominates. Recent evaluations conclude that the EGS technologies are still under development (Breede et al. 2013).

Although in theory geothermal energy is available all year round all over the world, its use shows significant regional disparities. Geological aspects such as the proximity to plate boundaries, a suitable subsurface for heat pump installations, or the availability of a technology needed for extraction are just some aspects that help to explain regional patterns. However, technologies are characterized by the interplay of natural and technological elements but also from mental and conceptual frameworks and specific knowledge sets, legal frameworks, political conditions, and organizational structures in its development as well as in its application and distribution (cf. Bijker and Law 1992; Hess 2005; Latour 1990). The usage of technologies also plays itself out in daily routines, cultural values, knowledge, and skills. When adopting an innovative technology into the existing sociotechnical system of heat and electricity provision, sociocultural factors can be as important as technical aspects or economic performance of the technology. As regards the two families of geothermal technology, the social context differs profoundly. While the use of shallow geothermal energy mainly takes place at the household level and involves homeowners as well as installation firms, energy consultants, architects, etc., deep geothermal installations are subject to large-scale technologies that require major investments by energy supply companies. Also, the legal framework and administrative responsibility as well as public perception of and response to the technology differ between shallow and deep geothermal energy (Moser and Stauffacher 2015). Within this article, we will focus on shallow geothermal energy technology.

Quite in contrast to the relevance of social elements in technological design and development, only little social research exists that addresses shallow geothermal energy explicitly. The most intensively researched aspect so far has been users' motivations in decisions for geothermal heat installation on the household level (Kölbel et al. 2008; Caird and Roy 2011; Hee et al. 2013). To further contribute to this research stream, we comparatively discuss the results of these studies and draw conclusions on underlying values. Another sociotechnical issue addressed in the context of geothermal energy is the question of user-driven innovation. We will take up this issue to employ the concept of "prosumption" to discuss potentially new roles of users in technology development.

Our aim within this article is based on a review of existing research revealing sociocultural aspects relevant for geothermal energy usage and technology and pointing to research needs in order to explain the social side of technology. By so doing, we will discuss the following questions:

- What motivations by homeowners for or against geothermal energy technology can be observed? (Section 3)

- How is the technology of shallow geothermal energy shaped in the interplay between actors from science, engineering, administration, and civil society? (Section 4)

- How can regional differences in technology diffusion be explained? (Section 5) 
Our arguments are based on ongoing debates in science and technology studies (STS), environmental sociology, and engineering studies that argue that any attempt to analyze energy users must take into consideration a multifaceted set of roles, values, and practices in order to understand how and why users modify and re-design, and how and why the public rejects, accepts, or adapts to new technologies (cf. Eglash et al. 2004; Oudshoorn and Pinch 2005; Park and Ohm 2015).

\section{Methods}

We rely on several data sources and methods: existing studies and statistics as well as our own fieldwork that have been carried out in 2013 and 2014 in Germany. The latter has been part of the integrated research project Energy Land Use at Leipzig's Helmholtz Centre for Environmental Research-UFZ.

We build on seven studies on homeowners' decision for heat pumps that have been carried out in Switzerland (1), Germany (4), the UK (1), and North Carolina, USA (1). Albeit these studies are quite heterogeneous concerning their foci (e.g., technologies studied) and overall research question, methods (e.g., questions asked, comparative approach, or focus on just one technology), and sample size (between 30 and 1023, see Table 1), they all address similar crucial questions on users' decisions for the implementation of heat pump technologies at a household level. We compiled the results with regard to our research question in Section 3.

In order to discuss regional disparities in installing ground source heat pumps, we relied on data provided by the German Federal Statistical Office. These were analyzed using methods of frequency analysis. The results will be discussed in Section 5 .

We also use our own empirical material that has been gathered via face-to-face interviewing using a semi-structured interview guideline to strengthen and complement our observations and arguments. Between 2013 and 2014, expert interviews with 16 persons-homeowners, employees of the municipal and regional administration, representatives of drilling companies, engineers, architects, and scientists-have been carried out in the city of Cologne and the Federal State of Saxony (Germany). Individual interviews lasted between $45 \mathrm{~min}$ up to 2 hours. These interviews have been transcribed and analyzed with the help of MAXqda, a computer software for qualitative data analysis. A coding scheme was developed in a twofold approach: using concepts already known from existing studies (e.g., environmental awareness) and revealing new concepts directly from the material (e.g., the code to cover the pioneering spirit of interviewees) (cf. Kuckartz 2007).

Furthermore, discussion threads at some important German online platforms on geothermal energy at household level were reviewed, and this information has been used to illustrate arguments that have been developed based on systematic analysis of statistical data and interview material. At platforms such as www.niedrigenergieforum.de, www.energieportal24.de, and www.haustechnikdialog.de, homeowners and energy experts discuss issues concerning heating technology. The issues range from the basic search of information on the appropriate heating technology up to questions on specific technological details. 
Table 1 Studies on user motivation

\begin{tabular}{|c|c|c|c|c|}
\hline Study & Technology & Region & Sample size & $\begin{array}{l}\text { Motivational factors (in the } \\
\text { order of their importance) }\end{array}$ \\
\hline \multicolumn{5}{|c|}{ Studies dealing exclusively with ground source heat pump systems } \\
\hline $\begin{array}{l}\text { Kölbel et al. } 2009 \text { (survey } \\
\text { carried out in 2007) } \\
\text { Focus on motivational factors } \\
\text { of risers who received a grant }\end{array}$ & $\begin{array}{l}\text { Ground } \\
\text { source heat } \\
\text { pump }\end{array}$ & $\begin{array}{l}\text { Germany, } \\
\text { Federal State } \\
\text { of Baden- } \\
\text { Wurttemberg }\end{array}$ & $\begin{array}{l}\text { About } \\
1000\end{array}$ & $\begin{array}{l}\text { - Increasing fuel prices } \\
\text { - Active personal contribution } \\
\text { to environmental protection } \\
\text { - Use of innovative } \\
\text { technology (Further criteria: } \\
\text { cleanliness of the } \\
\text { technology, compact size) }\end{array}$ \\
\hline $\begin{array}{l}\text { Sawillion } 2010 \text { (survey carried } \\
\text { out in 2007/2008) } \\
\text { Technical aspects treated } \\
\text { dominantly; several questions } \\
\text { on user's motivations were asked }\end{array}$ & $\begin{array}{l}\text { Ground } \\
\text { source heat } \\
\text { pump }\end{array}$ & $\begin{array}{l}\text { Germany, } \\
\text { Federal State } \\
\text { of Baden- } \\
\text { Wurttemberg }\end{array}$ & 145 & $\begin{array}{l}\text { - Environmentally friendly } \\
\text { technology } \\
\text { - Economic feasibility } \\
\text { (Further reasons: security of } \\
\text { supply, manageability, } \\
\text { independence from fossil } \\
\text { fuels, personal interest } \\
\text { in the technology) }\end{array}$ \\
\hline
\end{tabular}

Studies dealing with different technologies but revealing results for ground source heat pump systems explicitly

\begin{tabular}{|c|c|c|c|c|}
\hline $\begin{array}{l}\text { Roy et al. 2008, Caird and } \\
\text { Roy } 2011 \text { (date of the } \\
\text { survey not found) }\end{array}$ & $\begin{array}{l}\text { - Ground } \\
\text { source heat } \\
\text { pump } \\
\text { - Solar } \\
\text { thermal hot } \\
\text { water } \\
\text { - Wood- } \\
\text { fuelled } \\
\text { boilers } \\
\text { - Automatic } \\
\text { pellet-fed } \\
\text { biomass } \\
\text { room heaters } \\
\text { or stoves }\end{array}$ & UK & $\begin{array}{l}>900(89 \\
\text { GSHP) }\end{array}$ & $\begin{array}{l}\text { - To reduce } \mathrm{CO} 2 \text { emissions } \\
\text { - To save money on fuel bills } \\
\text { - The anticipated pleasure of } \\
\text { owning and using low or } \\
\text { zero-carbon technology }\end{array}$ \\
\hline $\begin{array}{l}\text { Hee et al. } 2013 \text { (survey } \\
\text { carried out in 2012) } \\
\text { Focus on user's motivation }\end{array}$ & $\begin{array}{l}\text { - Ground } \\
\text { source heat } \\
\text { pump } \\
\text { - Solar PV }\end{array}$ & $\begin{array}{l}\text { North } \\
\text { Carolina, USA }\end{array}$ & $\begin{array}{l}1023 \\
\text { (GSHP) }\end{array}$ & $\begin{array}{l}\text { - Costs of electricity bills } \\
\text { - To do something for the } \\
\text { environment }\end{array}$ \\
\hline
\end{tabular}

Studies dealing with several heat pump technologies without distinguishing or comparing the results concerning ground source and air-based heat pumps

\begin{tabular}{|c|c|c|c|c|}
\hline $\begin{array}{l}\text { Erb et al. } 2004 \text { (survey carried } \\
\text { out in 1997) } \\
\text { Focus on technical aspects; } \\
\text { motivational factors were an add-on }\end{array}$ & $\begin{array}{l}\text { - Ground } \\
\text { source heat } \\
\text { pump } \\
\text { - Air-based } \\
\text { heat pump }\end{array}$ & Switzerland & $\begin{array}{l}218 \text { (total } \\
\text { sample) }\end{array}$ & $\begin{array}{l}\text { - Environmentally friendly } \\
\text { heating system } \\
\text { - Space-saving technology }\end{array}$ \\
\hline $\begin{array}{l}\text { Michelsen and Madlener } 2013 \\
\text { (survey carried out in 2010) } \\
\text { Focus on motivational factors of } \\
\text { users who received a grant }\end{array}$ & $\begin{array}{l}\text { - Heat pump } \\
\text { - Oil- or gas- } \\
\text { fired con- } \\
\text { densing } \\
\text { boiler with } \\
\text { solar thermal } \\
\text { support } \\
\text { - Woodpellet- } \\
\text { fired boiler }\end{array}$ & Germany & $\begin{array}{l}2440 \text { (total } \\
\text { sample) }\end{array}$ & $\begin{array}{l}\text { - Multiple reasons without } \\
\text { clear preference on single } \\
\text { aspects (beneath these: } \\
\text { interest in the technology, } \\
\text { environmentally friendly } \\
\text { future technology, } \\
\text { independence from fossil } \\
\text { fuels) }\end{array}$ \\
\hline $\begin{array}{l}\text { Fall } 2014 \text { (survey carried out } \\
\text { in 2013/2014) } \\
\text { Focus on user's motivation }\end{array}$ & $\begin{array}{l}\text { - Ground } \\
\text { source heat } \\
\text { pump } \\
\text { - Air-based } \\
\text { heat pump }\end{array}$ & Germany & $\begin{array}{l}30 \text { (total } \\
\text { sample) }\end{array}$ & $\begin{array}{l}\text { - Independence from fossil } \\
\text { fuels } \\
\text { - Environmentally friendly } \\
\text { technology } \\
\text { - Economic feasibility } \\
\text { - Low-maintenance } \\
\text { technology } \\
\text { - Interesting innovative (new) } \\
\text { technology }\end{array}$ \\
\hline
\end{tabular}




\section{Using shallow geothermal heat: a technology for ecologically minded users}

After the oil crisis in the early 1970s when awareness for resource scarcity rose, in several countries, geothermal energy was seen as an alternative for heating and hot water provision, exploited by ground source heat pumps (GSHP) powered by electricity. Especially in Sweden the technology was met favorably. With the foundation of the Swedish Energy Agency in the 1970s, a structure was established to create and spread knowledge and to provide financial funding. Most publications ascribe the enormous number of installations in Sweden to these (geo-)political conditions: national policy and the subsequent organizational structures (cf. Lund et al. 2004; Lind 2010). Furthermore, it is assumed that using electrical heating, which was and still is widely practiced by the Swedish population, has a positive impact on using geothermal-based heating as the heat pump is also powered by electricity (Lind 2010). In other European countries such as France, Germany, or Switzerland, structures were established in order to promote geothermal energy in the early 2000s. In all these countries, installations of a GSHP are primarily a phenomenon of the new housing and single-family housing segment and less of the retrofit market (Forsén et al. 2008). Thus, decision-making of homeowners, usually middle-class people, has much influence on the further development of this technology.

Existing schemes of public and private funding are mostly interpreted as a major driver for the increasing use of shallow geothermal heat. However, several studies have been carried out in different countries on homeowners' motivation to decide for a GSHP (see Table 1). Results of these studies show that funding programs are not the main reason, if any, to decide for a GSHP facility. Especially when compared to decisions on other renewable energy technologies, the availability of public funding and other financial incentives for heat pumps generally and for GSHP more specifically is less important in decision-making (Michelsen and Madlener 2013; Hee et al. 2013). However, a study on microgeneration technologies in the UK revealed that those deciding against a GSHP did so due to purchase price and limited coverage of grants (Caird and Roy 2011).

Although the one-to-one comparability of these studies is impossible (see "Methods" section), some preliminary interpretations can be drawn on criteria in decision-making. First and foremost, the wish to invest in an environmentally friendly technology in all studies is an argument that ranks high and is even given as first or second reason (see Table 1). This correlates well with recent surveys on perceptions and public support of renewable energy transitions in general (cf. Eurobarometer 2007; AEE-Agentur für Erneuerbare Energien 2014). These studies show that a high environmental awareness and concern for the environment is closely related to support in transitions to renewable energies. Economic reasons do always play a role, be it by consideration of electricity bills (Hee et al. 2013) or by long-term considerations including operation costs (Sawillion 2010; Fall 2014). However, in Germany, users of online forums often emphasize that an exclusive focus on fossil fuel prices cannot be the basis of a decision for geothermal energy; a certain positive image of the technology and the decision for it as something ethically positive is needed. In the case of geothermal energy, the wish to be independent from the existing fuel-based energy system is an additional reason that fosters decisions towards investment into this renewable energy source on a household level. Interviews, online forums, and existing studies reveal that the idea of 
organizing its own energy independence on the household level is a strong individual motivation that comes into play in decision-making (cf. Sawillion 2010; Michelsen and Madlener 2013; Fall 2014). Finally, studies in Germany and in the UK reveal that a certain number of homeowners are technology enthusiasts who willingly carry out their own experiments with the innovative heating system (Michelsen and Madlener 2013; Fall 2014; Sawillion 2010; Caird and Roy 2011), despite uncertainty, e.g., as regards any knowledge about the project's payback period or clearly defined economic incentives.

Per contra other environmental-related issues (cf. Dunlap and Mertig 1997), a decision for GSHP technology thus seems to be more deeply rooted in post-material values (Inglehart 1977; Inglehart and Welzel 2005), especially the belief to contribute with this personal decision to the social goal of environmental protection since at least in Western cultures post-material attitudes and environmental concern form an integrated value cluster (cf. Mayerl and Best 2014).

Existing studies on a country level provide initial insights into how the technology is perceived and why homeowners decide for it. However, a well-grounded comparison between existing studies is hardly possible due to variations in methodologies. Furthermore, these studies only cover a small selection of countries or regions. Thus, countrywide and cross-country surveys focusing explicitly on sociocultural factors in using ground source heat pump technology and other microgeneration technologies could reveal sociocultural foundations of homeowners' decision-making.

\section{Co-design of shallow geothermal heat technology}

The GSHP is presented by interest groups such as national heat pump associations as a mature technology. However, it cannot be seen as ready-made. Unlike traditional heating systems and other renewables, each ground source heat pump installation forms a unified entity with the complex environmental system of the subsurface. Thus, each individual facility needs to be specifically designed. In Germany, normally several actors are involved in these designing processes: heating system installers, drilling companies, geologists, and environmental administrations. A higher engagement is also required by homeowners. Fall (2014) outlines that homeowners were invited by the engineers to co-design the facility. Information on user preferences as regards temperature, practices of heating, bathing, and showering are needed to set the parameters for the heating. Most users probably stay within this relatively small extent of technology modification that primarily helps to adjust and optimize the technological system to the specific (local) requirements. However, some of the homeowners and users tend to take an active role and modify and design single parts of the entities of their heating system. Postings at specific online platforms where users write about their experiences with their heating system show that these users have detailed knowledge on the technology and its components (pump, downhole heat exchanger, etc.). In their study on heat pump use in Finland, Hyysalo et al. (2013) called the engaged heat pump users the "inventive energy users." We would like to link this idea back to Alvin Toffler who coined the term "prosumption" when he referred to a close coupling between the production and the consumption of goods (Toffler 1980). While consumption and production have been separated for a long time in capitalist economy, due to social changes in many areas of production, especially those connected to media and internet, prosumption has gained a greater centrality in current capitalism (Blättel-Mink and Hellmann 2009; 
Ritzer and Jurgenson 2010). In the same way that production is rarely distinct from consumption, consumption of, for instance, raw materials also always takes place in production sites such as factories. The tendency to overcome the separation of consumption and production also can be observed in using and producing renewable energies. Thus, citizens active in energy production can be labeled as "energy prosumers" (Gross and Mautz 2015). The term is thus used to refer to the fact that, especially in the domestic sector, the roles of energy consumer and producer as well as between technology user and inventor are tightly coupled due to the introduction of householdor community-level energy-producing technologies.

These observations add new aspects to the traditional image of rather passive homeowners who just want to have a well-heated house and are not interested in technological details as revealed in some of the studies cited above. In spite of the relative complexity of heat pump technologies, users are able to (and in some cases have to) overcome the prescribed role of "energy consumer" and actively think about their heating, bathing, but also gardening practices. They have to make decisions on technological details (e.g., horizontal or vertical systems) and become intimately familiar with the technology. Novelty of technologies often calls for this. Thus, the design of each geothermal facility, the application of knowledge created within these individual cases, and its transition to other cases in many ways drive the development of geothermal heat technology. Users engage within these processes as do engineers. They thus influence primarily the design of their own facility but indirectly, e.g., via installers who take the experience made with one installation to further projects, the impulses are given for the general design. Knowledge creation should be interpreted as a collective endeavor.

More research is needed to understand how the system of using geothermal heat is designed and co-produced by interactions of diverse actors-homeowners, administration, and policy-and how discourses on environmental protection, renewable energy, or energy independence impact the implementation and diffusion of geothermal heat technology within the heating sector. It has to be analyzed if and how the collaborative design of the technology changes in the course of the innovation process. The study by Hyysalo et al. (2013) indicates that users are more deeply engaged in the design of the technology when its diffusion is still low.

\section{Cultural rifts? Regional diversity in the use of shallow geothermal energy}

Policy, institutional structures, personal motivations, and cultural beliefs form regional patterns of technology invention. In Germany, regional figures clearly show that the share of heat pumps in new homes has been much higher in the eastern than in the western part of the country since the early 2000s (cf. Figs. 1 and 2).

Figure 1 shows the share of all heat pump systems. Figure 2 reveals that in the eastern federal states-those states in the territory of the formerly socialist Germany, the GDR - the share of ground source heat pumps has been twice as high as the German average and even more than the average of the western states in 2010 and 2011. Although no comprehensive explanation is possible based on existing data, some hypotheses on the regional disparities can be made.

One explanation can be seen in different institutional developments. In western Germany, the system of installing heating systems in individual homes was established over several decades without deep societal ruptures. Thus, installation firms in the 


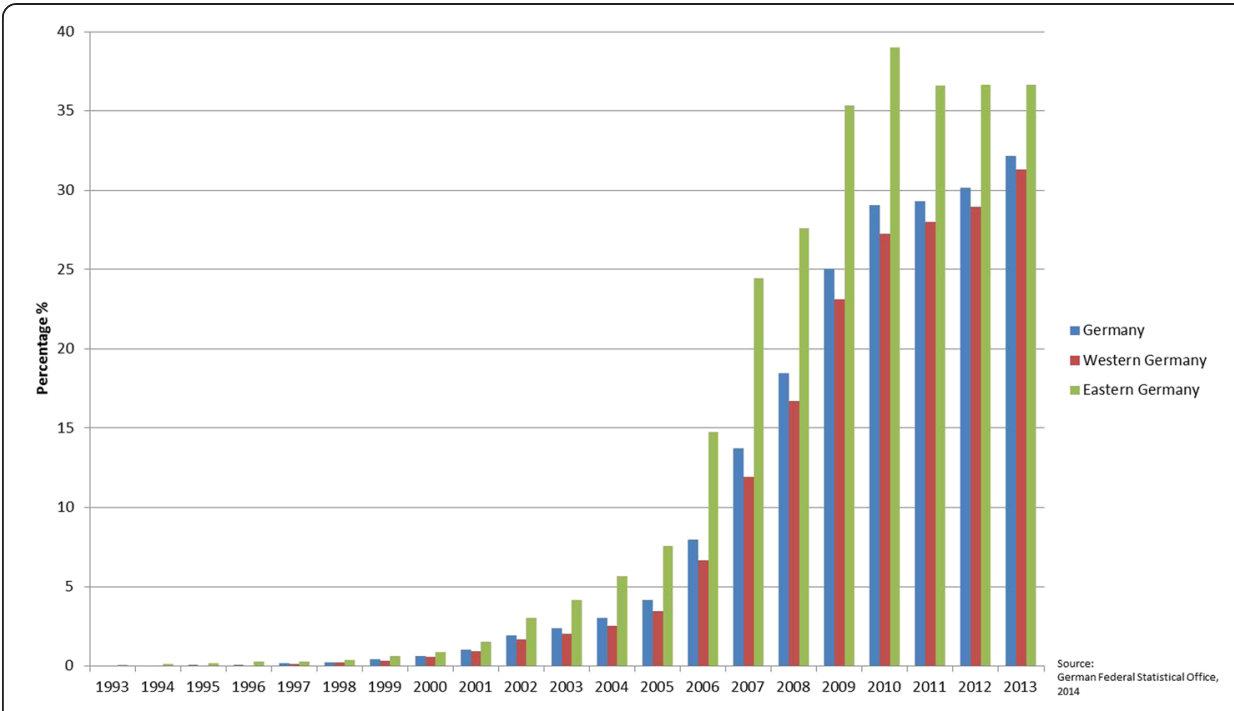

Fig. 1 Share of heat pumps in new homes. These data represent all types of heat pump-based systems — ground source as well as air-based systems. Figures of the Federal Heat Pump Association indicate a decreasing share of GSHP in favor of air-based heat pumps since 2008

western part became especially familiarized with oil-based technology (which was the major heating technology since the 1950s), and it is demanding to change to the complex technology of ground source heat pumps that requires specific knowledge about geological conditions that so far is not available in these firms. As an interviewee from Cologne in western Germany stated, existing structures and routines are interpreted as being unfavorable and challenging for innovative technologies: "When we thought for the first time about installing a GSHP in 2002, it was really a marginal topic. Definitely it was too new, especially for the local administration. As far as I know they had no experience with this technology at this time. They could understand that we wanted to abandon oil but they didn't understand why we didn't want to opt for gas-fired technology. The effort to convince the administration of an even more innovative technology

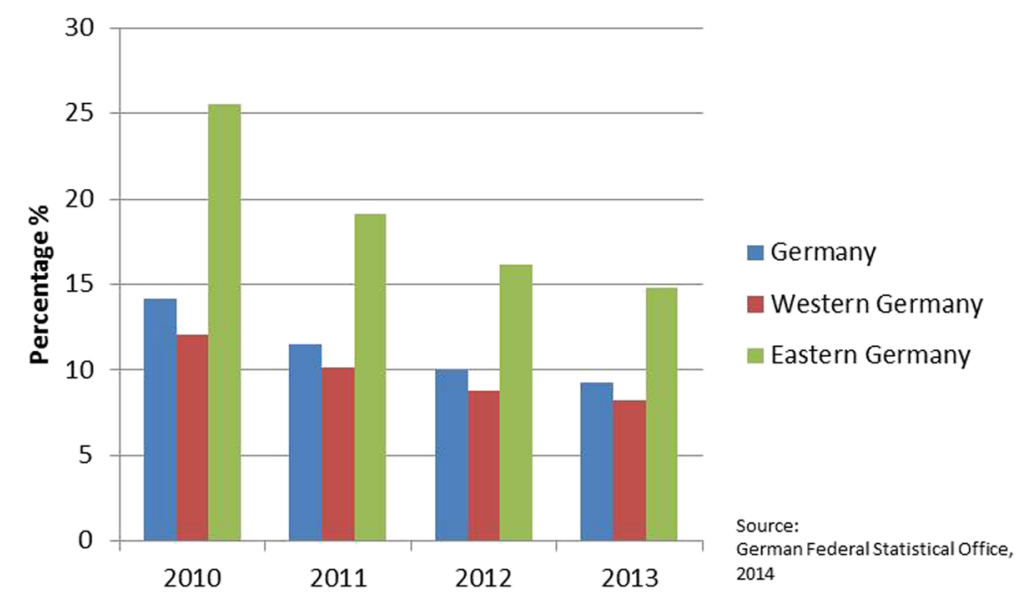

Fig. 2 Share of ground source heat pumps in new homes. Since 2010, the Federal Statistic Agency has distinguished between air-based and ground source heat pumps. For previous periods, the data are not separately available 
seemed to us too big. That is why we abandoned the idea of GSHP at this time" (Interview homeowner, 2013) ${ }^{1}$. This example nicely illustrates how technological paths on heating technologies are inscribed in social structures and institutions and how these structures guide people's actions (Dosi 1982). Per contra, in the eastern, formerly socialist, part the whole sector of home building was fundamentally restructured in the mid-1990s after the German reunification. Installation firms were funded and had to build up their competences, and people in environmental administrations had to learn a new legal system anyway. One could thus argue that heat pump technology (GSHP) met the institutional structure in an early stage and thus could be more easily adopted (cf. Collingridge 1980). Following Collingridge, in the early stages of a technology, it is comparably easy to adapt to or even change a technology since its social and cultural factors are not yet deeply enrooted in daily practices.

A second explanation for these regional disparities could be seen in the tradition of considering geothermal heat as an energy source for heating. Considerations on using deep geothermal energy in district heating in eastern Germany dates back to the 1980s under socialist rule when the search for alternative and domestic energy sources also resulted in a program for technology development and investigation of the geothermal energy potential (Schneider 2007). Some of the researchers in geology and engineers already involved in geothermal energy in the 1980s made use of their knowledge in the context of the market economy by founding companies in this field. Moreover, it can be hypothesized that these activities left a rather positive image of geothermal energy in the broader public as well as a general positive attitude towards innovative technologies and the idea of energy independence.

A third explanation could be the greater openness towards electric heating in the eastern federal states. Since the 1990s, also this type of heating shows a greater share in the eastern part and reached a peak of $6.8 \%$ in 2002, while at the same time in western states, the share was $1.4 \%$. Seeing that this explanation is also given for geothermal energy development in Sweden, it might also help to explain the difference between eastern and western Germany.

However, in order to validate these hypotheses and potentially find more explanations for those regional patterns, surveys would be needed that focus on motives of homeowners in heating system installation. More in-depth qualitative studies of funding schemes and administrative practices could be able to deliver answers on such regional disparities observed within and between nation states.

\section{Conclusions}

Nowadays, shallow geothermal technologies are considered part of renewable energy strategies in different countries. In addition to technical aspects and questions of ecological impacts of the technology (Vienken et al. 2015), cultural meanings and discourses as well as national policies and national and regional funding schemes form these technologies.

To sum up, the issues discussed in this paper include:

- Although economic reasoning does play a role in decision-making, it is not the major reason. Homeowners decide to install geothermal heating devices in their homes mainly due to the wish to engage for a better environment. Furthermore, the belief that this technology will enable greater energy independence from 
traditional energy suppliers and the interest in innovative technologies guide their decision-making. Seeing the importance of environmental arguments, we argued that a decision for a GSHP is more deeply rooted in post-material values.

- Geothermal technologies are not only developed by engineers and scientists. Society, groups of people, or individuals (e.g., homeowners) co-design the technology by choosing it for their home or by questioning potential risks. Feedback channels such as online platforms or knowledge transfer via engineers and installers can lead to changes in technology and lead for example to improvement of security standards. This phenomenon correlates with recent observations of the rise of "prosumers" that is of an increasing rate of co-design of products by the same group of people who will in the end also use them.

- There are cultural differences in acceptance of the technology. We exemplified this by discussing and comparing data from eastern and western Germany. The differences in the distribution of shallow geothermal energy installations may be rooted not only in different institutional developments since the early 1990s but also in a fundamentally different way of perceiving the geological underground as a place for energy utilization stemming from the pre-1990 socialist era.

Although the GSHP technology in Germany and other countries already entered the stage of diffusion, it is a technology that still has to find its place on par with other heating technologies. Meanwhile, the technology is continuously shaped in the interplay between users, engineers, installers, and administration. The negotiations in this interplay have to deal with upcoming uncertainties, e.g., the quality of materials for subsurface installations or environmental effects of high numbers of GSHP in small areas.

Given uncertainties in establishing geothermal energy systems, decision-making in processes of tapping geothermal energy sources and related areas necessitates acknowledgment that these uncertainties are an inevitable given (cf. Gross 2013). Where the development of the technology and knowledge generation about its application coincides, users thus elevate from mere consumers to energy prosumers. This trend thus should not to be misunderstood as irresponsible technology development, but as a part of a trend of increasing needs and wishes of customers to more individualistic products. Thus understood, GSHP development and prosumer choices appear to be at the forefront of developing customized technologies.

\section{Endnote}

${ }^{1}$ All direct interview quotes in this article, for ethical reasons, remain anonymous.

Competing interests

The authors declare that they have no competing interests.

Authors' contributions

Both authors have made equally substantive intellectual contributions to the article. Both authors read and approved the final manuscript.

Authors' information

$A B$ is a researcher at the Helmholtz Centre for Environmental Research. Her research in the last years was focused on sociocultural aspects of developing geothermal energy technologies in the context of their application. MG is a professor of environmental sociology at the University of Jena and, by joint appointment, the Helmholtz Centre for Environmental Research-UFZ, Leipzig, Germany. His research areas include alternative energy systems, risk and nonknowledge, and the sociology of engineering and innovation. 


\section{Acknowledgements}

We thank the reviewers for their constructive comments.

\section{Disclosure}

The research has been carried out in the frame of the authors' affiliations at the Helmholtz Centre for Environmental Research and the Integrated Project (IP) Energy Land Use.

\section{Author details}

${ }^{1}$ Helmholtz Centre for Environmental Research, UFZ, Permoser Str. 15, 04318 Leipzig, Germany. ${ }^{2}$ University of Jena, Institute of Sociology, Helmholtz Centre for Environmental Research, UFZ, Permoser Str. 15, 04318 Leipzig, Germany.

Received: 15 April 2015 Accepted: 8 June 2015

Published online: 02 July 2015

\section{References}

Bijker WE, Law J (1992) General introduction. In: Bijker WE, Law J (eds) Shaping technology/building society: studies in sociotechnical change. MIT Press, Cambridge

Blättel-Mink B, Hellmann KU (eds) (2009) Prosumer revisited: Zur Aktualität einer Debatte. VS, Wiesbaden

Breede K, Khatia D, Xiaolei L, Falcone G (2013) A systematic review of enhanced (or engineered) geothermal systems: past, present and future. Geothermal Energy, 1(4). doi:10.1186/2195-9706-1-4.

Caird S, Roy R (2011) Yes in my back yard: UK householders pioneering microgeneration technologies. In: Devine-Wright P (ed) Renewable energy and the public: from NIMBY to participation. Earthscan, London

Collingridge D (1980) The social control of technology. Pinter, London

Dosi G (1982) Technological paradigms and technological trajectories: a suggested interpretation of the determinants and directions of technical change. Res Policy 11(3):147-162

Dunlap RE, Mertig AG (1997) Global environmental concern: an anomaly for postmaterialism. Social Science Quarterly 78(1):24-29

Eglash R, Crossiant J, Di Chiro G, Fouché R (eds) (2004) Appropriating technology: vernacular science and social power University of Minnesota Press, Minneapolis

Erb M., Hubacher P, Ehrbar M (2004) Feldanalyse von Wärmepumpenanlagen - FAWA. Schlussbericht, Bundesamt für Energie BfE. Available via Bundesamt für Energie BFE. http://www.bfe.admin.ch/dokumentation/energieforschung/ index.html?lang=de\&publication=8070. Accessed 8 April 2015.

AEE - Agentur für Erneuerbare Energien (2014) Bürger stehen weiterhin hinter dem Ausbau erneuerbarer Energien. Ergebnisse der Akzeptanzumfrage, RENEWS KOMPAKT, 23. Available via Agentur für Erneuerbare Energien. http://www.unendlich-viel-energie.de/media/file/383.AEE_RenewsKompakt_23_Akzeptanzumfrage2014.pdf. Accessed 8 April 2015.

Eurobarometer (2007) Energy technologies: knowledge, perception, measures. Special Eurobarometer 262. Available via European Commission. http://ec.europa.eu/public_opinion/archives/ebs/ebs_262_en.pdf. Accessed 8 April 2015.

Fall S (2014) Erfolgsfaktoren und Barrieren bezüglich der Verbreitung, Akzeptanz und korrekten Handhabung von Wärmepumpen. Unpublished report. Available via Fraunhofer ISE. http://wp-effizienz.ise.fraunhofer.de/german/ index/index.html.

Forsén M, Roots P, Bertenstam A-L (2008) Marked status of ground source heat pumps in Europe, Deliverable 2 of the Project GROUND-REACH. Available via European Commission. http://ec.europa.eu/energy/intelligent/projects/sites/ iee-projects/files/projects/documents/ground-reach_market_status_for_gchp_in_europe.pdf. Accessed 8 April 2015.

Garnish JD (1976) Geothermal energy as an 'alternative' source. Energy Policy 4:130-143

Gross M (2013) Old Science Fiction, New Inspiration: Communicating Unknowns in the Utilization of Geothermal Energy. Science Communication 35(6), 810-818.

Gross M, Mautz R (2015) Renewable energies. Routledge, London

Hee CA, Wedding C, Urlaub I (2013) Motivations and behaviors of solar PV and geothermal system owners in North Carolina, online publication. Available via NC Sustainable Energy Association. http://c.ymcdn.com/sites/ www.energync.org/resource/resmgr/Resources_Page/NCSEA_solarpvgeo.pdf. Accessed 8 April 2015.

Hess DJ (2005) Technology- and product-oriented movements: approximating social movement studies and science and technology studies. Sci Technol Hum Val 30(4):515-535

Hyysalo S, Juntunen JK, Freeman S (2013) User innovation in sustainable home energy technologies. Energ Policy 55:490-500

Inglehart R (1977) The silent revolution: changing values and political styles among western publics. Princeton University Press, Princeton

Inglehart R, Welzel C (2005) Modernization, cultural change and democracy: the human development sequence. Cambridge University Press, Cambidge, UK

Kölbel T, Münch W, König R, Leucht M, Campillo-Bermudo G (2009) Erdwärme aus Kundensicht, bbr Sonderheft., pp 88-94

Kuckartz U (2007) Einführung in die computergestützte Analyse qualitativer Daten. VS Verlag, Wiesbaden

Latour B (1990) Technology is society made durable. In: Law J (ed) A sociology of monsters: essays on power technology and domination. Routledge, London

Lind L (2010) Swedish ground source heat pump case study. GNS Science Report 2010/54

Lund JW, Sanner B, Rybach L, Curtis L, Hellström G (2004) Geothermal (ground-source) heat pumps-a world overview. GHC Bull 2004:1-10

Lund JW, Freeston D, Derek H, Boyd TL (2011) Direct utilization of geothermal energy 2010 worldwide review. Geothermics 40:159-180

Mayerl J, Best H (2014) Theoretische und statistische Modellierung von Cross-Pressures in Kontextanalysen. Kölner Zeitschrift für Soziologie und Sozialpsychologie 66(1):135-154 
Michelsen CC, Madlener R (2013) Motivational factors influencing the homeowners' decisions between residential heating systems: an empirical analysis for Germany. Energ Policy 57:221-233

Moser C, Stauffacher M (2015) Literature review: public perception of geothermal energy. In: Hirschberg S, Wiemer S, Burgherr $\mathrm{P}$ (eds) Energy from the earth: deep geothermal as a resource for the future? vdf Hochschulverlag, Zürich, pp 297-306

Oudshoorn N, Pinch T (eds) (2005) How users matter: the co-construction of users and technology. MIT Press, Cambridge, MA

Park E, Ohm, J (2015) Appropriate Technology for Sustainable Ecosystems: Case Studies of Energy Self-Reliant Villages and the Future of the Energy Industry. Sustainable Development 23(2), 74-83.

Ritzer G, Jurgenson N (2010) Production, consumption, prosumption. The nature of capitalism in the age of the digital 'prosumer'. J of Consumer Cult 10:13-36

Roy R, Caird S, Abelman J (2008) YIMBY generation—yes in my back yard! UK householders pioneering microgeneration heat. The Energy Saving Trust, London, UK. Available via Open University. http://oro.open.ac.uk/ 10828/1/24660_EST.pdf. Accessed 8 April 2015.

Sawillion M (2010) Evaluierung von bestehenden Erdwärmesonden-Wärmepumpen. bbr - Sonderheft., pp 14-20

Schneider H (2007) Geothermie in Ostdeutschland (1977 bis 1990). In: Hartmann O, Guntau M, Pälchen W (eds) Zur Geschichte der Geowissenschaften in der DDR, Schriftenreihe für Geowissenschaften 16. Verlag Störr, Ostklüne

Toffler A (1980) The third wave. Bantam Books, New York

Vienken T, Schelenz S, Rink K, Dietrich P (2015) Sustainable intensive thermal use of the shallow subsurface-a critical view on the status quo. Groundwater 53:356-361

Submit your manuscript to a SpringerOpen ${ }^{\oplus}$ journal and benefit from:

- Convenient online submission

Rigorous peer review

- Immediate publication on acceptance

- Open access: articles freely available online

- High visibility within the field

- Retaining the copyright to your article 